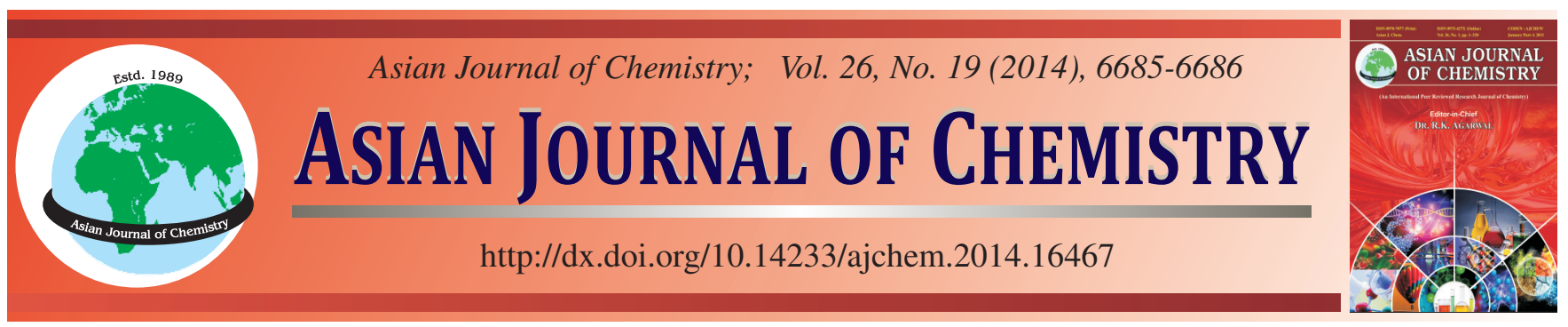

NOTE

\title{
A New Xanthone from the Stems of Garcinia oligantha and their Anti-tobacco Mosaic Virus Activity
}

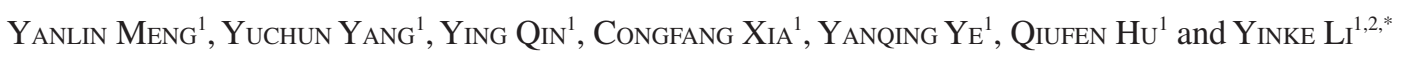

${ }^{1}$ Key Laboratory of Chemistry in Ethnic Medicinal Resources, State Ethnic Affairs Commission and Ministry of Education, Yunnan University of Nationalities, Kunming 650031, P.R. China

${ }^{2}$ Collge of Resource and Environment, Yuxi Normal University, Yuxi 653100, P.R. China

*Corresponding author: E-mail: linkli609@126.com

Received: 4 October 2013;

Accepted: 17 April 2014;

Published online: 16 September 2014;

AJC-15988

For more bioactive compounds, phytochemical investigations of the methanol extract of the stems of Garcinia oligantha resulted in the isolation of a new xanthone, (S)-1,8-dihydroxy-4-(1-hydroxy-3-oxobutyl)-3-methoxy-9H-xanthen-9-one (1). Structural elucidation of 1 was performed by spectral methods. Compound 1 showed anti-tobacco mosaic virus (anti-TMV) activities with inhibition rates of $15.2 \%$.

Keywords: Xanthone, Garcinia oligantha, Anti-tobacco mosaic virus activity.

Genus Garcinia (Guttiferae family) is known to be a rich source of polyisoprenylated benzophenones and xant-hones ${ }^{1,2}$. It has been widely used as a traditional Chinese medicine for treating toothache, sore mouth, and scald ${ }^{3}$. In our continuing efforts to finding more bioactive compounds from Garcinia species, we explored the chemical constituents of G. oligantha, a shrub 1-3 m tall, which is distributed in 200-1200 m dense forests in the district of Xishuangbanna Prefecture Yunnan province, People's Republic of China. The present studies on chemical constituents of the methanol extract of the dried stems of $G$. oligantha afforded a new xanthones, (S)-1,8-dihydroxy4-(1-hydroxy-3-oxobutyl)-3-methoxy-9H-xanthen-9-one (1) (Fig. 1). In this paper, we describe the isolation, structure elucidation, and anti-tobacco mosaic virus (anti-TMV) activities of this compound.

Optical rotations were measured by a JASCO DIP-1000 polarimeter. Ultraviolet absorption spectra were recorded using<smiles>COc1cc(O)c2c(=O)c3c(O)cccc3oc2c1[C@H](O)CC(C)=O</smiles>

Fig. 1. Structure of compound 1 a Perkin-Elmer Lambda L14 spectrometer. A Perkin Elmer spectrum 100 FT-IR spectrometer was used for scanning IR spectroscopy. The ${ }^{1} \mathrm{D}$ and ${ }^{2} \mathrm{D}$ NMR spectra were recorded on a Bruker AV-400 spectrometer with TMS as the internal standard. Chemical shifts $(\delta)$ were expressed in ppm with reference to the solvent signals. HRMS were obtained using a nano LC-MS/MS system, with a nano Acquity ultra-performance liquid chromatography (UPLC) module and a quadrupole time-of-flight (Q-TOF) spectrometer equipped with a nanoelectrospray ion source (Waters, Milford, MA) and connected to a lock-mass apparatus to perform a real-time calibration correction. Column chromatography was performed with silica gel (200-300 mesh, Qingdao Marine Chemical, Inc.), Sephadex LH-20 (Pharmacia), and reversed-phase $\mathrm{C}_{18}$ silica gel (250 mesh, Merck). Precoated TLC sheets of silica gel $60 \mathrm{GF}_{254}$ were used. An Agilent 1200 series equipped with an Alltima $\mathrm{C}_{18}$ column $(4.6 \times 250 \mathrm{~mm})$ was used for HPLC analysis, and semipreparative and preparative Alltima $\mathrm{C}_{18}$ columns or Zorbax SB- $\mathrm{C}_{18}$ columns $(9.4 \times 250$ and $22 \times 250$ $\mathrm{mm}$ ) were used in sample preparation. Spots were visualized by heating silica gel plates sprayed with $10 \% \mathrm{H}_{2} \mathrm{SO}_{4}$ in $\mathrm{EtOH}$.

The stems of Garcinia oligantha were collected in October 2012 from the district of Xishuangbanna Prefecture Yunnan Province in China. The plant was identified by Rong-Jing Zhang. A voucher specimen (YNNI 12-9-27) has been deposited at the Key Laboratory of Ethnic Medicine Resource Chemistry (Yunnan University of Nationalities), State Ethnic Affairs Commission \& Ministry of Education. 
Extraction and isolation: An methanol extract prepared from the stems of Garcinia oligantha $(2.5 \mathrm{~kg})$ was decolorized by MCI and chromatographed on a silica gel column eluting with hexane/acetone $(1: 0,4: 1,2: 1,1: 1$, and $0: 1)$ to afford five fractions A-E. Further separation of fraction B (11.5 g) on silica gel, eluted with petroleum ether-acetone (9:1-1:2), yielded fractions B1-B7. Fraction B2 (2.65 g) was subjected to silica gel column chromatography using petroleum ether-acetone followed by semipreparative HPLC $\left(72 \% \mathrm{MeOH}-\mathrm{H}_{2} \mathrm{O}\right.$, flow rate $3 \mathrm{~mL} / \mathrm{min})$ to give $1(8.6 \mathrm{mg})$.

(S)-1,8-Dihy droxy - 4-(1-hydroxy -3-oxobutyl)-3methoxy-9H-xanthen-9-one (1): Obtained as a yellow gum; $[\alpha]_{\mathrm{D}}^{22.5}-45.6(c 0.25, \mathrm{MeOH}) ; \mathrm{UV}(\mathrm{MeOH}) \lambda_{\max }(\log \varepsilon) 210$ (4.18), 244 (3.72), 302 (3.75) nm; CD (MeOH, c 0.25) $\Delta \varepsilon_{215}+$ 1.26, $\Delta \varepsilon_{235}-5.96, \Delta \varepsilon_{274}+0.38, \Delta \varepsilon_{320}-0.98 ;$ IR $\left(\mathrm{KBr} v_{\max }, \mathrm{cm}^{-1}\right)$ 3421, 3065, 2870, 2802, 1708, 1646, 1602, 1565, 1470, 1351, 1166, 1062, 878, 765; ESIMS $\mathrm{m} / z$ (positive ion mode) 367 $[\mathrm{M}+\mathrm{Na}]^{+}$; HRESIMS (positive ion mode) $\mathrm{m} / z, 367.0790[\mathrm{M}$ $+\mathrm{Na}]^{+}\left(\right.$calcd $\mathrm{C}_{18} \mathrm{H}_{16} \mathrm{NaO}_{7}$ for 367.0794).

Compounds (1) was isolated as a yellow gum, and its molecular formula was determined as $\mathrm{C}_{18} \mathrm{H}_{16} \mathrm{NaO}_{7}$ through HRESI-MS analysis (pseudomolecular ion $[\mathrm{M}+\mathrm{Na}]^{+}$at $\mathrm{m} / z$ 367.0790). Its UV spectrum showed the maximum absorption at 302, 244, and $210 \mathrm{~nm}$. Strong absorption bands accounting for hydroxy $\left(3421 \mathrm{~cm}^{-1}\right)$, carbonyl $\left(1708,1646 \mathrm{~cm}^{-1}\right)$, and aromatic groups $\left(1602,1565,1470 \mathrm{~cm}^{-1}\right)$ could also be observed in its IR spectrum. The ${ }^{1} \mathrm{H}-$ and ${ }^{13} \mathrm{C}$ NMR spectrum (Table-1) displayed signals for all 18 carbons and 16 protons, including a xanthones skeleton ${ }^{4}$ (C-1-C-9, C-4a, C-8a-C-10a; H-2, H-5-H-7), a methoxy groups $\left(\delta_{\mathrm{C}} 55.9 \mathrm{q}, \delta_{\mathrm{H}} 3.82 \mathrm{~s}\right)$, a 1-hydroxy-3-oxobutyl moiety ${ }^{5}$ $\left[\delta_{\mathrm{C}} 63.7 \mathrm{~d}, 51.2 \mathrm{t}, 205.4 \mathrm{~s}, 31.2 \mathrm{q} ; \delta_{\mathrm{H}} 5.18 \mathrm{dd}(8.8,3.2), 2.82 \mathrm{dd}\right.$ $(15.4,3.2), 2.46 \mathrm{dd}(15.4,8.8), 2.18 \mathrm{~s}]$, and two phenolic hydroxyl group $\left(\delta_{\mathrm{H}} 12.24 \mathrm{~s}\right.$ and $\left.13.05 \mathrm{~s}\right)$. The HMBC correlation (Fig. 2) of the methoxy proton signal $\left(\delta_{\mathrm{H}} 3.82\right)$ with $\mathrm{C}-3\left(\delta_{\mathrm{C}} 161.2\right)$ showed this methoxy group was located at $\mathrm{C}-3$. The long-range correlations of H-1' $\left(\delta_{\mathrm{H}} 5.18\right)$ to $\mathrm{C}-3\left(\delta_{\mathrm{C}} 161.2\right), \mathrm{C}-4\left(\delta_{\mathrm{C}} 110.3\right)$ and $\mathrm{C}-4 \mathrm{a}\left(\delta_{\mathrm{C}} 156.4\right)$, of $\mathrm{H}_{2}-2^{\prime}\left(\delta_{\mathrm{H}} 2.82\right.$ and 2.46$)$ to $\mathrm{C}-4\left(\delta_{\mathrm{C}}\right.$ $110.3)$ were observed in $\mathbf{1}$. This led us to conclude that the 1hydroxy-3-oxobutyl moiety was located on C-4. Finally, HMBC correlations between the hydroxy proton $\left(\delta_{\mathrm{H}} 12.24\right)$ and $\mathrm{C}-1\left(\delta_{\mathrm{C}}\right.$ $162.5), \mathrm{C}-2\left(\delta_{\mathrm{C}} 97.4\right)$, and $\mathrm{C}-9 \mathrm{a}\left(\delta_{\mathrm{C}} 105.7\right)$, as well as those between the other hydroxy proton $\left(\delta_{\mathrm{H}} 13.05\right)$ and $\mathrm{C}-7\left(\delta_{\mathrm{H}} 108.2\right)$, $\mathrm{C}-8\left(\delta_{\mathrm{H}} 162.9\right)$, and $\mathrm{C}-8 \mathrm{a}\left(\delta_{\mathrm{H}} 107.5\right)$, led to the assignment of the phenolic groups at $\mathrm{C}-1$ and $\mathrm{C}-8$. The typical proton signals of ring $\mathrm{A}\left[\delta_{\mathrm{H}} 6.85 \mathrm{~d}(8.3), 7.42 \mathrm{t}(8.3), 6.65 \mathrm{~d}(8.3)\right]$ and ring $\mathrm{B}\left(\delta_{\mathrm{H}}\right.$ $6.47 \mathrm{~s}$ ) also supported that 1 should be a 1,3,4,8-tetrasubstituted xanthone ${ }^{4}$. To determine the absolute configuration of $\mathbf{1}$, the circular dichroism (CD) analysis was employed. The experimental CD spectrum of $\mathbf{1}$ exhibited a positive Cotton effect at $215 \mathrm{~nm}$ and a negative Cotton effect near $235 \mathrm{~nm}$. The Cotton effects, optical rotation, and coupling constant valves of $\mathbf{1}$ were in excellent agreement with these of known compound $d^{5},(1 ' S)$ 7-hydroxy-3-(1'-hydroxy-3'-butanoyl) chromone-5-carboxylic acid. Therefore, compound $\mathbf{1}$ was assigned as (S)-1,8-dihydroxy4-(1-hydroxy-3-oxobutyl)-3-methoxy-9H-xanthen-9-one.

Since certain chromones exhibit potential ant-TMV activities $^{4,6,7}$, compounds $\mathbf{1}$ was tested for it anti-TMV activity. The inhibitory activities of compound $\mathbf{1}$ against TMV repli-

\begin{tabular}{ccc}
\multicolumn{3}{c}{ TABLE-1 } \\
\multicolumn{4}{c}{$\begin{array}{c}{ }^{1} \mathrm{H} \text { AND }{ }^{13} \mathrm{C} \text { NMR DATA OF COMPOUND 1 } \\
\left(\delta \text { in ppm, in } \text { }_{5} \mathrm{D}_{5} \mathrm{~N}, 500 \text { AND } 125 \mathrm{MHz}\right)\end{array}$} \\
\hline No. & $\delta_{\mathrm{C}}(\mathrm{m})$ & $\delta_{\mathrm{H}}(\mathrm{m}, \mathrm{J}, \mathrm{Hz})$ \\
\hline 1 & $162.5 \mathrm{~s}$ & - \\
2 & $97.4 \mathrm{~d}$ & $6.47 \mathrm{~s}$ \\
3 & $161.2 \mathrm{~s}$ & - \\
4 & $110.3 \mathrm{~s}$ & - \\
5 & $112.5 \mathrm{~d}$ & $6.85 \mathrm{~d}(8.3)$ \\
6 & $135.7 \mathrm{~d}$ & $7.42 \mathrm{t}(8.3)$ \\
7 & $108.2 \mathrm{~d}$ & $6.65 \mathrm{~d}(8.3)$ \\
8 & $162.9 \mathrm{~s}$ & - \\
9 & $183.1 \mathrm{~s}$ & - \\
$4 \mathrm{a}$ & $156.4 \mathrm{~s}$ & - \\
$8 \mathrm{a}$ & $107.5 \mathrm{~s}$ & - \\
$9 \mathrm{a}$ & $105.7 \mathrm{~s}$ & - \\
$10 \mathrm{a}$ & $159.0 \mathrm{~s}$ & - \\
$1^{\prime}$ & $63.7 \mathrm{~d}$ & - \\
$2^{\prime}$ & $51.2 \mathrm{t}$ & $2.82 \mathrm{dd}(15.4,3.2) ; 2.46 \mathrm{dd}(15.4,8.8)$ \\
$3^{\prime}$ & $205.4 \mathrm{~s}$ & $2.18 \mathrm{~s}$ \\
$4^{\prime}$ & $31.2 \mathrm{q}$ & $3.82 \mathrm{~s}$ \\
$3-\mathrm{OMe}$ & $55.9 \mathrm{q}$ & $12.24 \mathrm{~s}$ \\
Ar-OH-1 & - & $13.05 \mathrm{~s}$ \\
Ar-OH-8 & - & \\
\hline
\end{tabular}

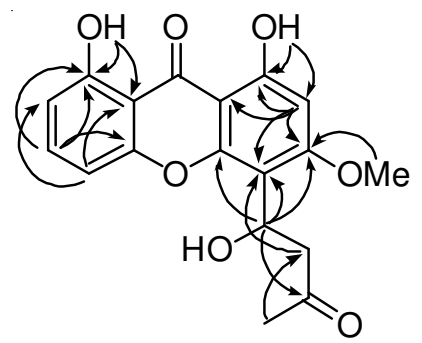

Fig. 2. Key HMBC ( $\neg$ ) correlations of $\mathbf{1}$

cation were tested using the half-leaf method ${ }^{6}$. Ningnanmycin, a commercial biochemical pesticide against virus diseases on tomato, pepper, melons, tobacco, and many other crops with high efficiency, was used as a positive control. The result showed that compound $\mathbf{1}$ exhibited inhibition rates of $15.2 \%$.

\section{ACKNOWLEDGEMENTS}

This research was supported by the National Natural Science Foundation of China (No. 21362044), the Basic Research Foundation of Yunnan Tobacco Industry Co. Ltd (2012JC01), the Excellent Scientific and Technological Team of Yunnan High School (2010CI08), the Yunnan University of Nationalities Green Chemistry and Functional Materials Research for Provincial Innovation Team (2011HC008).

\section{REFERENCES}

1. X.M. Gao, T. Yu, F. Lai, Y. Zhou, X. Liu, C.F. Qiao, J.Z. Song, S.L. Chen, K.Q. Luo and H.X. Xu, Bioorg. Med. Chem., 18, 4957 (2010).

2. Q. Hu, X. Gao, D. Niu, X. Li, Y. Qin, Z. Yang, G. Zhao, Z. Yang and Z. Chen, Heterocycles, 87, 1127 (2013).

3. A. Libman, S. Bouamanivong, B. Southavong, K. Sydara and D.D. Soejarto, J. Ethnopharmacol., 106, 303 (2006).

4. Y.P. Wu, W. Zhao, Z.Y. Xia, G.H. Kong, X.P. Lu, Q.F. Hu and X.-M. Gao, Phytochem. Lett., 6, 629 (2013).

5. M. Gan, Y. Liu, Y. Bai, Y. Guan, L. Li, R. Gao, W. He, X. You, Y. Li, L. Yu and C.L. Xiao, J. Nat. Prod., 76, 1719 (2013).

6. Q.F. Hu, B. Zhou, J.-M. Huang, X.-M. Gao, L.-D. Shu, G.-Y. Yang and C.-T. Che, J. Nat. Prod., 76, 292 (2013).

7. Q.F. Hu, B. Zhou, X.M. Gao, L.Y. Yang, L.D. Shu, Y.Q. Shen, G.P. Li, C.T. Che and G.Y. Yang, J. Nat. Prod., 75, 1909 (2012). 